\title{
A rare case of Corynebacterium Spp. native mitral valve endocarditis - case report and review of literature
}

\author{
(D)Krešimir Kordić1*, \\ (DNikola Kos', \\ (DNikola Bulj', \\ (D) Matias Trbušić', \\ (DIvo Darko Gabrić', \\ (D) Ozren Vinter', \\ (i)Igor Rudež², \\ (DDiana Delić-Brkljačićc
}

'University Hospital Centre "Sestre milosrdnice", Zagreb, Croatia

${ }^{2}$ University Hospital Dubrava, Zagreb, Croatia
RECEIVED:

May 7, 2018

ACCEPTED:

May 10, 2018

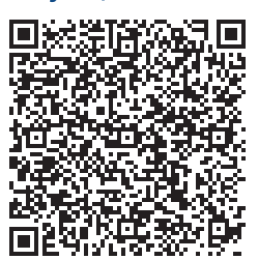

KEYWORDS: endocarditis, Corynebacterium, mitral valve. CITATION: Cardiol Croat. 2018;13(5-6):206. | https://doi.org/10.15836/ccar2018.206

*ADDRESS FOR CORRESPONDENCE: Krešimir Kordić, Klinički bolnički centar Sestre milosrdnice, Vinogradska cesta 29, HR-10000 Zagreb, Croatia. / Phone: +385-98-1921-263 / E-mail: kordic.kresimir@yahoo.com

ORCID: Krešimir Kordić, https://orcid.org/0000-0002-9707-6946 • Nikola Kos, https://orcid.org/0000-0001-8829-2543 Nikola Bulj, https://orcid.org/0000-0002-7859-3374 • Matias Trbušić, https://orcid.org/0000-0001-9428-454X Ivo Darko Gabrić, https://orcid.org/0000-0003-4719-4634 • Ozren Vinter, https://orcid.org/0000-0002-4236-7594 Igor Rudež, https://orcid.org/0000-0002-7735-6721 • Diana Delić-Brkljačić, https://orcid.org/0000-0002-7116-2360

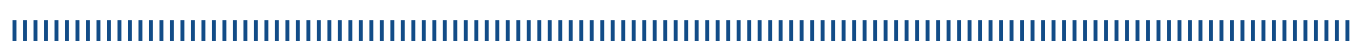

Background: Corynebacteria species are non-fermentous Gram-positive bacilli considered part of a human skin and mucos membranes flora and are commonly isolated in clinical specimens. They are not recognized as common cause of endocarditis. ${ }^{1-3}$ We report a case of native mitral valve infective endocarditis caused by Corynebacterium spp.

Case report: 45-year-old male with a history of spinal cord injury and paraplegia presented with a 20-day history of fever and fatigue. Before starting antibiotics, multiple blood samples were taken and Corynebacterium spp was isolated. Due to unknown source of infection and a new systolic heart murmur, a transesophageal echocardiography was performed, showing severe mitral regurgitation with two mobile hypoechogenic masses on the anterior and posterior mitral valve leaflets, 11x5 mm and 6x5 $\mathrm{mm}$, respectively. According to antibiogram, vancomycin was administered, and the fever subsided. The patient was transferred to a Cardiac Surgery Department, where he underwent mitral valve replacement (On-X M 25/33). The resected vegetation was culture-negative. Postoperatively, pericardiocentesis was performed due to increasing pericardial effusion. Afterwards, the patient was discharged and presented free of infection and without pericardial effusion at the two-month follow up.

Conclusion: According to available data, there is a growing incidence of non-diphtheriae Corynebacterium endocarditis, particularly as a part of nosocomial infections or in immunocompromised patients. In most of the cases the affected valve was mitral or aortic, mostly affecting native valves. There is high incidence of multiple résistance to standard antibiotics in Corynebacterium causing endocarditis. We presented a case of native mitral valve infective endocarditis caused by Corynebacterium spp. $\square$ Cardiologia Croatica 2018;13(5-6):206.

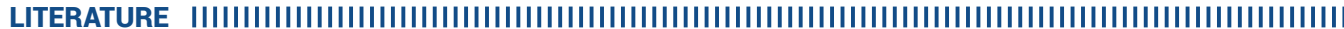

1. Abdelfattah M, Koya R, Kuhn-Basti M, Amdo T. Corynebacterium Are Not Just Contaminants: A Case of Corynebacterium Endocarditis of a Native Valve. Chest. 2016;150(4):400A. https://doi.org/10.1016/j.chest.2016.08.413

2. Belmares J, Detterline S, Pak JB, Parada JP. Corynebacterium endocarditis species-specific risk factors and outcomes. BMC Infect Dis. 2007 Feb 6:7:4. https://doi.org/10.1186/1471-2334-7-4

3. Hong HL, Koh HI, Lee AJ. Native Valve Endocarditis due to Corynebacterium striatum confirmed by 165 Ribosomal RNA Sequencing: A Case Report and Literature Review. Infect Chemother. 2016 Sep;48(3):239-245. https://doi.org/10.3947/ic.2016.48.3.239 